\title{
Effects of Recruiting Midwives into a Family Physician Program on the Indices of Maternal Health Program in the Rural Areas of Kurdistan
}

\author{
Shayesteh Hajizadeh ${ }^{1}$, Fahimeh Ramezani Tehrani ${ }^{2}$, Masoumeh Simbar $^{1} \&$ Farshad Farzadfar $^{3}$ \\ ${ }^{1}$ Midwifery and Reproductive Health Department, Faculty of Nursing and Midwifery, Shahid Beheshti \\ University of Medical Sciences, Tehran, Iran \\ ${ }^{2}$ Gynecology Department, Reproductive Endocrinology Research Center, Research Institute for Endocrine \\ Sciences, Shahid Beheshti University of Medical Sciences, Tehran, Iran \\ ${ }^{3}$ Non-Communicable Diseases Research Center, Endocrinology and Metabolism Population Sciences Institute, \\ Tehran University of Medical Sciences, Tehran, Iran \\ Correspondence: Fahimeh Ramezani Tehrani, Reproductive Endocrinology Research Center, Research Institute \\ for Endocrine Sciences, ShahidBeheshti University of Medical Sciences, Tehran, I. R. of Iran, Tel/Fax: \\ 98-21-2243-2500. E-mail: Ramezani@endocrine.ac.ir
}

Received: November 23, 2015 Accepted: January 18, 2016 Online Published: February 29, 2016

doi:10.5539/gjhs.v8n11p92

URL: http://dx.doi.org/10.5539/gjhs.v8n11p92

\begin{abstract}
A family physician program has been implemented in rural areas of the country since the early 2005.Therefore, due to the increase in the density of midwives in this project, it is expected that more services would be provided to pregnant women. This cross-sectional study used the difference-in-differences model and Matchit statistical model to compare the indices of maternal health program before and after the implementation of a family physician program. It compared health centres that had increase in their density of midwives in the course of the study with those that did not. The study sample consisted of 668 mothers of 2-month-old children in 2013. Data were collected using a questionnaire that was administered in structured interviews. In this study, in $2013,38.8 \%$ of the women received preconception care, $66.5 \%$ received prenatal care and $41.6 \%$ received postpartum care, as defined by the standards. Based on the results of statistical models of difference-in-differences analyses and Matchit, there was no significant change in indices of maternal health program between 2005 and 2013. The results of this study showed that an increase in the density of midwives in a family physician program did not have an impact on the indices of maternal health program; it indicated that the increase in the density of midwives alone was not efficient. In other words, the quality of primary health care is strongly dependent on the use of trained health workers. In addition, manpower planning and management can have an important role in improvement of prenatal care.
\end{abstract}

Keywords: family physician program, prenatal care, postnatal care, healthcare system

\section{Introduction}

Primary care services have a critical role in achieving the Sustainable Development Goals (SDGs); in view of that, the World Health Organization in 2008 used the slogan 'primary health care now more than ever' to emphasize that the expansion of primary health care is a main strategy to improve health and reduce costs (World Health Organization [WHO], 2008).

After the remarkable success of health care services in reducing mortality and improving fertility in rural areas, in recent years, health care systems of the Islamic Republic of Iran have made fundamental changes in the delivery of medical services in villages and towns with population $<20,000$ (Ministry of Health and Medical Education $[\mathrm{MOH}], 2012)$. In the family physician program, health teams, which include doctors, midwives, behavrzes and other technicians, provide services for 2000-4000 individuals. The payment system is based on the number of population under the coverage and quality of services. The teams are responsible for promoting public health, providing primary health care and, if necessary, referring to the next level. After referral to higher levels of expertise, family physicians and their team are responsible for later follow-ups. All health care services for the population are actively provided by the family physician program and followed up through household 
visits (MOH, 2012).

In the early years of the establishment of the health system in the country, the health of mothers and children received special attention from policymakers. At that time, increasing people's access to prenatal, postnatal and neonatal health programs was considered as a health priority, and after the introduction of a health network in the country, the access to services increased. After increasing people's access to health services, it was necessary to increase the quality of services via designing an appropriate approach to rapidly diagnose and refer mothers at risk to specialists (MOH, 2009).

The results of the national plan for monitoring and evaluation of maternal and neonatal health program, in the second half of 2005, in rural areas of Kurdistan province, showed that the coverage of preconception care services was $16.39 \%$; in addition, $26.5 \%$ of the women received prenatal care services consistent with the pre-defined standards (MOH, 2008). Based on the findings of some studies, between the years 2001 and 2006, the two most important factors affecting maternal mortality in Kurdistan Province included the following: age above 35 years and inappropriate prenatal and postnatal care (Keshtkar, Changizi, \& Majdzadeh, 2008).

The family physician program has been implemented in rural areas of the country since the early 2005 . Moreover, due to the increase in the density of midwives in this project, it is expected that more services would be provided to pregnant women; this health care service team can actively provide services within referral system and rural insurance coverage and consequently promote maternal health in health centres (MOH, 2012).

To reduce inequities and revise policies, it is essential to monitor and evaluate interventions. It is important for health care workers to monitor and evaluate the impact of proposed policies on access, utilization and quality of services for disadvantaged groups (Lyell \& McDonnell, 2008). Quality, effectiveness, efficiency and availability of health care services primarily depend on the performance of health workers (Mohammad-Alizadeh et al., 2009). Service providers can utilize the results obtained from the review of the effectiveness of intervention programs; the results of the review can have a great impact on their performance and, therefore, the quality of the services they offer (Langer et al., 1998).

On the other hand, after three decades, the country is now going to implement the family physician program and establish referral system in the cities of Iran and it is the third turning point in the reconstruction of health services. Before the expansion of the program to urban areas, it is necessary to make a comprehensive assessment of family physician program in the areas of design, implementation and outcomes; the results of the assessment can be used to receive financial and political support needed to execute the program in urban areas and can be also used to identify obstacles, limitations and deficiencies in the implementation of the program in the rural areas. Consequently, scientific evidences can be used to reform the delivery of services in rural areas.

Therefore, this study was designed and aimed to compare the indices of prenatal care before and after the implementation of family physician program in health centres where the density of midwives increased compared with the health centres where it did not.

\section{Method}

\subsection{Study Design}

This cross-sectional study aimed to determine the effects of recruiting midwives into a family physician program on the indices of maternal health program. The health centres that implemented a family physician program in this study were divided into two groups: health centers that had increase in their density of midwives during the study's time frame and health centres that had no change in their density of midwives during the same period. Maternal health program indices were compared between participants who sought preventative care for their child at the health center belonging to one of these two groups.

\subsection{Participant Characteristics}

Data collected from mothers who had been referred to the village health houses and health centers to vaccinate their 2-month-old children.

\subsection{Sampling Procedures}

The unprocessed data that was used as our source of data prior to establishing the family physician program in 2005 was from the National Plan for Monitoring and Evaluation of Reproductive Health Programs .The researcher collected the data after the implementation of family physician program in 2013. Consistent with the sampling method used for the monitoring and evaluation of reproductive health programs in 2005, the 2013 sampling was conducted in the same village health houses, using the same sample size. 


\subsubsection{Sample Size}

The study sample consisted of 668 mothers of 2-month-old children in 2013.These mothers were selected from the population of all mothers with 2-month-old children who were referred to health centres for vaccinations of their 2-month old infants.

\subsubsection{Measures and Covariates}

The data collection tool for the study was questionnaire was used for monitoring and evaluation of reproductive health programs in 2005.An expert committee of the Ministry of Health and Medical Education had tested this questionnaire for validity and reliability in the years 2002-2004(Ministry of Health and Medical Education, 2008).

\subsubsection{Definition of Variables}

Socioeconomic data: The characteristics of the villages covered by the health centres were collected, including data on schools, electricity, piped water, gas pipelines, mailboxes, public Internet access and public transportation access and access to newspapers, banks and stores. These data were collected for the years 2005 and 2013. The information about the villages were collapsed at the level of health centres and weighted based on the population of each village. The collected data were used to assess the socioeconomic status of the study setting using principal component analysis (PCA) so that the percentage of variance explained the first factor and reached Rho $=0.2630$. By removing variables that had high unexplained percentages, the percentage of the variance that explained the first factor reached $\mathrm{Rho}=0.4023$.

Maternal health program indices: The indicators representing the outcomes of maternal health program. These indices include the coverage of services and continuity of care and are defined as follows.

Continuity of prenatal care: Delivery of prenatal care for a total of eight times during the pregnancy, delivery of prenatal care for two times up to the 20th week of pregnancy (until the 4th gestational month); delivery of prenatal care for three times at the 26th to 37 th gestational weeks $(6,7$ and 8 months); delivery of prenatal care for three times at the 38 th to 40 th gestational weeks ( 9 month).

Continuity of postnatal care: A total of three times of postnatal care during the 1st to 3rd days after delivery, 15th to 21 th days after delivery and 42 th to 60 th days after delivery.

The percentage of mothers who received preconception care as defined by the standards: it is the percentage of pregnant women who received standard preconception care consistent with the integrated health care services designed for maternal health.

The percentage of mothers who received prenatal care as defined by the standards: it is the percentage of pregnant women who received standard prenatal care consistent with the integrated health care services designed for maternal health.

The percentage of mothers who received postnatal care as defined by the standards: it is the percentage of pregnant women who received standard postnatal care consistent with the integrated health care services designed for maternal health.

The density of rural community health (Behvarz) workers, family physicians or midwives was calculated as the total number of professionals per 1000 persons in the population.

The village health house: It is the most peripheral health delivery facility in rural areas and the place from which the behvarz works. Each health house is designed to cover a target population of about 1500 .

\subsection{Data Analysis}

After completing the questionnaire and checklists, the collected data was analysed using R and STATA software. To determine the effects of family physician programs on factors associated with caesarean section rates, we used statistical models, including the difference-in-differences model and non-parametric and parametric combined models, of which Matchit was the most appropriate model. We used Matchit model because propensity score matching is a powerful method for to evaluate community-based interventions and clarify the causal relations; it is used when the random implementation of an intervention is neither practical nor ethical. This method can help to reduce selection bias, which is common in observational studies (Jiang, Foster, \& Gibson-Davis, 2011; Harder, Stuart, \& Anthony, 2010).

The intervention was not randomly applied to the health centers, so Matchit was used to show that the changes in indices associated with caesarean section rates before and after the intervention had happened under equal conditions. For this reason, the Average Treatment Effect (ATE) was calculated. 
To neutralize the effects of randomly assignment to different districts, the districts of Kurdistan province were entered into the model as indicator variables.

\section{Results}

The average age of mothers in the study sample was 28 years in $2013.15 .9 \%$ were illiterate, $90 \%$ were housewives and $96 \%$ had been pregnant less than five times. In addition, $5.4 \%$ of mothers were smokers or drug users and $12.3 \%$ of mothers had a history of high-risk medical or obstetric conditions in 2013 (Table 1).

The results of this study showed that of all mothers, $16.5 \%$ in 2005 and $67.4 \%$ in 2013 received preconception care (Table 1). However, only $4.4 \%$ in 2005 and $38.8 \%$ in 2013 received full preconception care, as defined by the standards.

$98.9 \%$ in 2005 and $99.4 \%$ in 2013 received prenatal care. However, $32.5 \%$ in 2005 and $66.5 \%$ in 2013 received full prenatal care, as defined by the standards. Moreover, $79 \%$ in 2005 and $90 \%$ in 2013 received at least eight times of prenatal care. $14.8 \%$ in 2005 and $41.6 \%$ in 2013 received full postnatal care, as defined by the standards. Moreover, $43.7 \%$ in 2005 and $73.5 \%$ in 2013 received at least three times the postnatal care.

Table 1. Characteristics of the study population in the survey of 2005 and 2013

\begin{tabular}{|c|c|c|c|}
\hline \multirow{2}{*}{ Variable } & \multirow{2}{*}{ Options } & \multicolumn{2}{|c|}{ Year of study(Sample size) } \\
\hline & & $2005(\mathrm{~N}=668)$ & $2013(\mathrm{~N}=668)$ \\
\hline \multirow[t]{3}{*}{ Age } & under 18 years old & $28(4.2 \%)$ & $12(1.8 \%)$ \\
\hline & 18 to 35 years old & $578(86.5 \%)$ & $556(83.2 \%)$ \\
\hline & Over 35 years old & $62(9.3 \%)$ & $100(15 \%)$ \\
\hline \multirow[t]{3}{*}{ Job } & Employed & $42(6.3 \%)$ & $67(10 \%)$ \\
\hline & Unemployed & $626(93.7 \%)$ & $601(90 \%)$ \\
\hline & Illiterate & $250(37 \%)$ & $106(15.9 \%)$ \\
\hline \multirow[t]{2}{*}{ Education } & Literate & $418(63 \%)$ & $562(84.1 \%)$ \\
\hline & Low risk $(<5)$ & $607(90.9 \%)$ & $641(96 \%)$ \\
\hline Parity & High risk $(>=5)$ & $61(9.1 \%)$ & $27(4 \%)$ \\
\hline \multirow[t]{2}{*}{ Smoking or drug abuse } & Yes & $86(12.9 \%)$ & $36(5.4 \%)$ \\
\hline & No & $582(87.1 \%)$ & $632(94.6 \%)$ \\
\hline \multirow[t]{2}{*}{ History of medical disease or high risk obstetrical condition } & Yes & $106(87.1 \%)$ & $586(87.7 \%)$ \\
\hline & No & $562(84.1 \%)$ & $450(67.4 \%)$ \\
\hline \multirow[t]{2}{*}{ Utilization of preconception care } & Yes & $110(16.5 \%)$ & $450(67.4 \%)$ \\
\hline & No & $558(83.5 \%)$ & $218(32.6 \%)$ \\
\hline \multirow[t]{2}{*}{ Standard preconception care } & Yes & $29(4.4 \%)$ & $259(38.8 \%)$ \\
\hline & No & $639(95.6 \%)$ & $409(61.2 \%)$ \\
\hline \multirow[t]{2}{*}{ Utilization of prenatal care } & Yes & $661(98.9 \%)$ & $664(99.4 \%)$ \\
\hline & No & $7(1.1 \%)$ & $4(0.6 \%)$ \\
\hline \multirow[t]{2}{*}{ Standard prenatal care } & Yes & $217(32.5 \%)$ & $444(66.5 \%)$ \\
\hline & No & $451(67.5 \%)$ & $224(33.5 \%)$ \\
\hline \multirow[t]{2}{*}{ Continuity of prenatal care } & Yes & $529(79 \%)$ & $601(90 \%)$ \\
\hline & No & $139(21 \%)$ & $67(10 \%)$ \\
\hline \multirow[t]{2}{*}{ Standard postnatal care } & Yes & $99(14.8 \%)$ & $278(41.6 \%)$ \\
\hline & No & $569(85.2 \%)$ & $390(58.4 \%)$ \\
\hline \multirow[t]{2}{*}{ Continuity of postnatal care } & Yes & $292(43.7 \%)$ & $491(73.5 \%)$ \\
\hline & No & $376(56.3 \%)$ & $177(26.5 \%)$ \\
\hline
\end{tabular}


According to the results of the difference-in-differences and Matchit model(Tables 2 and 5), there was no significant change in the index of preconception care in 2013 compared with 2005 in health centres where the density of midwives increased, compared with health centres where it did not.

Concerning other variables, which were entered into the difference-in-differences model, the results showed that the odds ratio of the utilization of preconception care in 2013 compared with 2005 was increased by more than fourfold; in addition, with increasing every one unit in the number of parities, it decreased by $20 \%$. The odds ratio of utilization of preconception care as defined by the standards in 2013 compared with 2005 had an increase of more than six fold.

According to the results of the difference-in-differences and Matchit model (Tables 3 and 5), there was no significant change in the index of prenatal care in 2013 compared with 2005 in health centres where the density of midwives increased, compared with health centres where it did not.

Results of the difference-in-differences and Matchit model(Tables 4 and 5) indicated that there was no significant change in the index of postnatal care in 2013 compared with 2005 in health centres where the density of midwives increased, compared with health centres where it did not.

In addition, the odds ratio of continuity of care among people who were satisfied with postnatal care services increased by more than two fold (Table 4).

Table 2. Relationship between variables and Preconception care and Standard preconception care as defined by the standards in rural areas of Kurdistan province (2005: $\mathrm{N}=668,2013: \mathrm{N}=668)$

\begin{tabular}{|c|c|c|c|}
\hline \multirow[t]{3}{*}{ Variable } & \multirow[t]{3}{*}{ Options } & $\begin{array}{l}\text { standard preconception care } \\
\text { (yes, no) }\end{array}$ & preconception care (yes, no) \\
\hline & & Difference in difference model & Difference in difference model \\
\hline & & $\mathrm{OR}(\mathrm{CI})$ & $\mathrm{OR}(\mathrm{CI})$ \\
\hline \multirow{2}{*}{$\begin{array}{l}\text { Interaction between } \\
\text { intervention and time }\end{array}$} & 1 & $0.42(0.11-1.61)$ & $0.68(0.32-1.44)$ \\
\hline & 0 & $\mathrm{P}=0.21$ & $\mathrm{P}=0.32$ \\
\hline \multirow[t]{2}{*}{ Year } & 2013 & $6.3(5.8-8.7)$ & $4.1(2.7-7.4)$ \\
\hline & 2005 & $\mathrm{P}<0.001$ & $\mathrm{P}<0.001$ \\
\hline \multirow{2}{*}{$\begin{array}{l}\text { Intervention (increase in the } \\
\text { density of midwives) }\end{array}$} & yes & $2.1(0.59-7.3)$ & $1.29(0.71-2.34)$ \\
\hline & No & $\mathrm{P}=0.25$ & $\mathrm{P}=0.39$ \\
\hline \multirow[t]{2}{*}{ Age } & \multirow{2}{*}{$\begin{array}{l}\text { Continuous } \\
\text { quantitative variable }\end{array}$} & $(0.97-1.04)$ & $(0.99-1.05)$ \\
\hline & & $\mathrm{P}=0.58$ & $\mathrm{P}=0.07$ \\
\hline \multirow[t]{2}{*}{ Parity } & \multirow{2}{*}{$\begin{array}{l}\text { Continuous } \\
\text { quantitative variable }\end{array}$} & $0.88(0.74-1.05)$ & $0.8(0.7-0.93)$ \\
\hline & & $\mathrm{P}=0.16$ & $\mathrm{P}=0.003$ \\
\hline \multirow[t]{2}{*}{ Education } & Illiterate & $1(0.64-1.55)$ & $1.14(0.8-1.62)$ \\
\hline & Literate & $\mathrm{P}=0.98$ & $\mathrm{P}=0.45$ \\
\hline \multirow[t]{2}{*}{ Job } & Employed & $0.71(0.42-1.22)$ & $0.87(0.54-1.39)$ \\
\hline & Unemployed & $\mathrm{P}=0.22$ & $\mathrm{P}=0.58$ \\
\hline \multirow[t]{2}{*}{ Smoking or drug abuse } & yes & $0.66(0.4-1.1)$ & $0.87(0.46-1.65)$ \\
\hline & No & $\mathrm{P}=0.11$ & $\mathrm{P}=0.69$ \\
\hline \multirow{2}{*}{$\begin{array}{l}\text { History of high risk medical or } \\
\text { obstetric conditions }\end{array}$} & yes & $0.82(0.51-1.31)$ & $0.82(0.55-1.21)$ \\
\hline & No & $\mathrm{P}=0.42$ & $\mathrm{P}=0.32$ \\
\hline \multirow[t]{2}{*}{ Density of family physicians } & \multirow{2}{*}{$\begin{array}{l}\text { Continuous } \\
\text { quantitative variable }\end{array}$} & $0.37(0.07-1.96)$ & $0.91(0.22-3.78)$ \\
\hline & & $\mathrm{P}=0.25$ & $\mathrm{P}=0.9$ \\
\hline \multirow{2}{*}{$\begin{array}{l}\text { Density of rural community } \\
\text { health (Bhevarz) workers }\end{array}$} & \multirow{2}{*}{$\begin{array}{l}\text { Continuous } \\
\text { quantitative variable }\end{array}$} & $0.89(0.69-1.16)$ & $0.88(0.71-1.1)$ \\
\hline & & $\mathrm{P}=0.4$ & $\mathrm{P}=0.28$ \\
\hline
\end{tabular}




\begin{tabular}{llll}
\hline Socio-economic status & $\begin{array}{l}\text { Continuous } \\
\text { quantitative variable }\end{array}$ & $\begin{array}{l}0.99(0.95-1.04) \\
\mathrm{P}=0.95\end{array}$ & $1(0.96-1.05)$ \\
Logarithm of the rural & Continuous & $1.2(0.78-1.78)$ & $\mathrm{P}=0.8$ \\
population & quantitative variable & $\mathrm{P}=0.43$ & $0.88(0.61-1.27)$ \\
Sex ratio & Continuous & $1.01(0.97-1.05)$ & $\mathrm{P}=0.5$ \\
& quantitative variable & $\mathrm{P}=0.52$ & $1(0.97-1.03)$ \\
& & $\mathrm{P}=0.95$ \\
\hline
\end{tabular}

Table 3. Relationship between variables and continuity of prenatal care and standard prenatal care in rural areas of Kurdistan province (2005: $\mathrm{N}=668,2013: \mathrm{N}=668$ )

\begin{tabular}{|c|c|c|c|}
\hline \multirow[t]{3}{*}{ Variable } & \multirow[t]{3}{*}{ Options } & \multicolumn{2}{|c|}{$\begin{array}{l}\text { continuity of prenatal care (yes, standard prenatal care (yes, no) } \\
\text { no) }\end{array}$} \\
\hline & & Difference in difference model & Difference in difference model \\
\hline & & $\mathrm{OR}(\mathrm{CI})$ & $\mathrm{OR}(\mathrm{CI})$ \\
\hline \multirow{2}{*}{$\begin{array}{l}\text { Interaction between } \\
\text { intervention and time }\end{array}$} & 1 & $1.29(0.53-3.13)$ & $0.95(0.51-1.79)$ \\
\hline & 0 & $\mathrm{P}=0.55$ & $\mathrm{P}=0.88$ \\
\hline \multirow[t]{2}{*}{ Year } & 2013 & $1.85(0.86-3.9)$ & $4.3(2.4-7.4)$ \\
\hline & 2005 & $\mathrm{P}=0.11$ & $\mathrm{P}<0.001$ \\
\hline \multirow{2}{*}{$\begin{array}{l}\text { Intervention (increase in the } \\
\text { density of midwives) }\end{array}$} & yes & $0.89(0.51-1.85)$ & $1.15(0.72-1.85)$ \\
\hline & No & $\mathrm{P}=0.0 .71$ & $\mathrm{P}=0.54$ \\
\hline \multirow[t]{2}{*}{ Age } & \multirow{2}{*}{$\begin{array}{l}\text { Continuous } \\
\text { quantitative variable }\end{array}$} & $0.99(0.96-1.03)$ & $1.01(0.98-1.03)$ \\
\hline & & $\mathrm{P}=0.8$ & $\mathrm{P}=0.42$ \\
\hline \multirow[t]{2}{*}{ Parity } & \multirow{2}{*}{$\begin{array}{l}\text { Continuous } \\
\text { quantitative variable }\end{array}$} & $0.77(0.67-0.9)$ & $1.02(0.91-1.14)$ \\
\hline & & $\mathrm{P}<0.001$ & $\mathrm{P}=0.69$ \\
\hline \multirow[t]{2}{*}{ Education } & Illiterate & $1.41(0.96-2.05)$ & $0.93(0.69-1.26)$ \\
\hline & Literate & $\mathrm{P}=0.7$ & $\mathrm{P}=0.67$ \\
\hline \multirow[t]{2}{*}{ Job } & Employed & $0.62(0.36-1.07)$ & $1.08(0.71-1.38)$ \\
\hline & Unemployed & $\mathrm{P}=0.09$ & $\mathrm{P}=0.95$ \\
\hline \multirow[t]{2}{*}{ Smoking or drug abuse } & yes & $0.98(0.57-1.68)$ & $0.87(0.58-1.32)$ \\
\hline & No & $\mathrm{P}=0.95$ & $\mathrm{P}=0.53$ \\
\hline \multirow{2}{*}{$\begin{array}{l}\text { History of high risk medical } \\
\text { or obstetric conditions }\end{array}$} & yes & $0.86(0.55-1.34)$ & $0.98(0.71-1.38)$ \\
\hline & No & $\mathrm{P}=0.52$ & $\mathrm{P}=0.95$ \\
\hline \multirow[t]{2}{*}{ Density of family physicians } & \multirow{2}{*}{$\begin{array}{l}\text { Continuous } \\
\text { quantitative variable }\end{array}$} & $0.44(0.7-2.47)$ & $1.13(0.32-3.93)$ \\
\hline & & $\mathrm{P}=0.35$ & $\mathrm{P}=0.85$ \\
\hline \multirow{2}{*}{$\begin{array}{l}\text { Density of rural community } \\
\text { health (Bhevarz) workers }\end{array}$} & \multirow{2}{*}{$\begin{array}{l}\text { Continuous } \\
\text { quantitative variable }\end{array}$} & $1.2(0.91-1.59)$ & $1.15(0.94-1.4)$ \\
\hline & & $\mathrm{P}=0.19$ & $\mathrm{P}=0.15$ \\
\hline \multirow[t]{2}{*}{ Socio-economic status } & \multirow{2}{*}{$\begin{array}{l}\text { Continuous } \\
\text { quantitative variable }\end{array}$} & $0.93(0.88-1.99)$ & $1(0.96-1.04)$ \\
\hline & & $\mathrm{P}=0.35$ & $\mathrm{P}=0.9$ \\
\hline \multirow{2}{*}{$\begin{array}{l}\text { Logarithm of the rural } \\
\text { population }\end{array}$} & \multirow{2}{*}{$\begin{array}{l}\text { Continuous } \\
\text { quantitative variable }\end{array}$} & $1.18(0.74-1.89)$ & $1.22(0.87-1.72)$ \\
\hline & & $\mathrm{P}=0.47$ & $\mathrm{P}=0.23$ \\
\hline \multirow[t]{2}{*}{ Sex ratio } & \multirow{2}{*}{$\begin{array}{l}\text { Continuous } \\
\text { quantitative variable }\end{array}$} & $0.98(0.57-1.68)$ & $1.02(0.99-1.05)$ \\
\hline & & $\mathrm{P}=0.13$ & $\mathrm{P}=0.06$ \\
\hline \multirow{2}{*}{$\begin{array}{l}\text { Satisfaction with prenatal } \\
\text { care }\end{array}$} & \multicolumn{2}{|l|}{ yes } & $0.72(0.41-1.27)$ \\
\hline & \multicolumn{2}{|l|}{ No } & $\mathrm{P}=0.26$ \\
\hline
\end{tabular}


Table 4. Relationship between variables and continuity of postnatal care and standard postnatal care in rural areas of Kurdistan province (2005: $\mathrm{N}=668,2013: \mathrm{N}=668$ )

\begin{tabular}{|c|c|c|c|}
\hline \multirow[t]{3}{*}{ Variable } & \multirow[t]{3}{*}{ Options } & $\begin{array}{l}\text { Continuity of postnatal care } \\
\text { (yes, no) }\end{array}$ & $\begin{array}{l}\text { Standard postnatal care (yes, } \\
\text { no) }\end{array}$ \\
\hline & & Difference in difference model & Difference in difference model \\
\hline & & $\mathrm{OR}(\mathrm{CI})$ & $\mathrm{OR}(\mathrm{CI})$ \\
\hline \multirow{2}{*}{$\begin{array}{l}\text { Interaction between } \\
\text { intervention and time }\end{array}$} & 1 & $0.98(0.52-1.87)$ & $1.03(0.51-2.08)$ \\
\hline & 0 & $\mathrm{P}=0.97$ & $\mathrm{P}=0.93$ \\
\hline \multirow[t]{2}{*}{ Year } & 2013 & $3.91(2.23-6.83)$ & $4.5(2.45-8.3)$ \\
\hline & 2005 & $\mathrm{P}<0.001$ & $\mathrm{P}<0.001$ \\
\hline \multirow{2}{*}{$\begin{array}{l}\text { Intervention (increase } \\
\text { in the density of } \\
\text { midwives) }\end{array}$} & yes & $1.03(0.66-1.61)$ & $0.77(0.43-1.37)$ \\
\hline & No & $\mathrm{P}=0.88$ & $\mathrm{P}=0.38$ \\
\hline \multirow[t]{2}{*}{ Age } & \multirow{2}{*}{$\begin{array}{l}\text { Continuous quantitative } \\
\text { variable }\end{array}$} & $0.99(0.96-1.02)$ & $0.98(0.95-1.01)$ \\
\hline & & $\mathrm{P}=0.59$ & $\mathrm{P}=0.19$ \\
\hline \multirow[t]{2}{*}{ Parity } & \multirow{2}{*}{$\begin{array}{l}\text { Continuous quantitative } \\
\text { variable }\end{array}$} & $0.98(0.88-1.11)$ & $1.11(0.98-1.26)$ \\
\hline & & $\mathrm{P}=0.85$ & $\mathrm{P}=0.1$ \\
\hline \multirow[t]{2}{*}{ Education } & Illiterate & $0.79(0.58-1.07)$ & $1.03(0.73-1.47)$ \\
\hline & Literate & $\mathrm{P}=0.13$ & $\mathrm{P}=0.83$ \\
\hline \multirow[t]{2}{*}{ Job } & Employed & $0.99(0.64-1.54)$ & $0.86(0.54-1.37)$ \\
\hline & Unemployed & $\mathrm{P}=0.98$ & $\mathrm{P}=0.54$ \\
\hline \multirow{2}{*}{$\begin{array}{l}\text { Smoking or drug } \\
\text { abuse }\end{array}$} & yes & $1.01(0.72-1.62)$ & $0.6(0.05-2.54)$ \\
\hline & No & $\mathrm{P}=0.77$ & $\mathrm{P}=0.3$ \\
\hline \multirow{2}{*}{$\begin{array}{l}\text { Density of family } \\
\text { physicians }\end{array}$} & \multirow{2}{*}{$\begin{array}{l}\text { Continuous quantitative } \\
\text { variable }\end{array}$} & $1(0.28-3.54)$ & $1.02(0.26-3.2)$ \\
\hline & & $\mathrm{P}=0.99$ & $\mathrm{P}=0.96$ \\
\hline \multirow{2}{*}{$\begin{array}{l}\text { Density of rural } \\
\text { community health } \\
\text { (Bhevarz) workers }\end{array}$} & \multirow{2}{*}{$\begin{array}{l}\text { Continuous quantitative } \\
\text { variable }\end{array}$} & $1.1(0.86-1.28)$ & $1.05(0.85-1.3)$ \\
\hline & & $\mathrm{P}=0.58$ & $\mathrm{P}=0.6$ \\
\hline \multirow[t]{2}{*}{ Socio-economic status } & \multirow{2}{*}{$\begin{array}{l}\text { Continuous quantitative } \\
\text { variable }\end{array}$} & $0.99(0.95-1.04)$ & $4.5(2.45-8.3)$ \\
\hline & & $\mathrm{P}=0.83$ & $\mathrm{P}=0.3$ \\
\hline \multirow{2}{*}{$\begin{array}{l}\text { Logarithm of the rural } \\
\text { population }\end{array}$} & \multirow{2}{*}{$\begin{array}{l}\text { Continuous quantitative } \\
\text { variable }\end{array}$} & $0.7(0.49-1.99)$ & $1.14(0.79-1.62)$ \\
\hline & & $\mathrm{P}=0.44$ & $\mathrm{P}=0.46$ \\
\hline \multirow[t]{2}{*}{ Sex ratio } & \multirow{2}{*}{$\begin{array}{l}\text { Continuous quantitative } \\
\text { variable }\end{array}$} & $0.99(0.97-1.02)$ & $1.09(0.98-1.04)$ \\
\hline & & $\mathrm{P}=0.91$ & $\mathrm{P}=0.25$ \\
\hline \multirow{2}{*}{$\begin{array}{l}\text { Satisfaction } \quad \text { with } \\
\text { postnatal care }\end{array}$} & \multicolumn{2}{|l|}{ yes } & $2.56(1.74-3.78)$ \\
\hline & \multicolumn{2}{|l|}{ No } & $\mathrm{P}<0.001$ \\
\hline
\end{tabular}


Table 5. Effect of increase in the density of midwives in family physician program on the indices of maternal health program in rural health centers in Kurdistan province (2005: $\mathrm{N}=668,2013: \mathrm{N}=668$ )

\begin{tabular}{llll}
\hline Variable & Matchit & & \\
\cline { 2 - 4 } & Average Treatment Effect & $95 \%$ Confidence Interval & High \\
\cline { 3 - 4 } & & Low & 0.17 \\
preconception care & 0.05 & -0.07 & 0.14 \\
Standard preconception care & 0.06 & -0.05 & 0.16 \\
Standard prenatal care & 0.05 & -0.06 & 0.1 \\
Continuity of prenatal care & 0.005 & -0.09 & 0.06 \\
Standard postnatal care & -0.04 & -0.17 & 0.11 \\
Continuity of postnatal care & 0.004 & -0.09 & \\
\hline
\end{tabular}

\section{Discussion}

The results of the difference-in-differences and Matchit model showed that there was no statistically significant change in the indices of coverage, continuity and utilization of maternal health care services, as defined by the standards in 2013 compared with 2005, in health centres where the density of midwives increased compared with health centres where it did not. These results are consistent with the results of the study on Mother and Child Health Indices in Rural Population Auspices of Mashhad (Raeissi, Ebadi Fard Azar, Roudbari, \& Shabanikia, 2011).

In family physician program the health teams are responsible for promoting public health, providing primary health care and, if necessary, referring to the next level. After referral to higher levels of expertise, they are responsible for later follow-ups. All health care services for the population are actively provided by the family physician program and followed up through household visits (MOH, 2012). But the results of a study by Bakhshian and Jabbari (2009) showed that referral system and presenting feedback from physicians, patients follow-up and completing health record in Family physician program in Iran is not implemented properly (Bakhshian \& Jabbari, 2009). Moreover, the results of a study that was conducted in Sanandaj of Kurdistan province, indicated that family physician program had no impact on the number of cases, which were detected and referred to hospital (Khayyati, Motlagh, Kabir, Kazemeini, \& Jafari, 2011).

However, the results of a study by Frankenberg and Thomas (2001) showed that the use of rural midwives had resulted in significant improvements in health, especially of women of childbearing age (Frankenberg \& Thomas, 2011). Furthermore, the use of safe motherhood program in rural areas of west China led to the improvement in the utilization of prenatal services (Liu, Yan, \& Wang, 2010).

According to the results obtained from the difference-in-difference model, all indices of maternal health program increased in 2013 compared with 2005. Their increases were statistically significant for the indices of preconception care, full utilization of preconception, prenatal and postnatal care (as defined by the standards) and the continuity of care.

A study in the rural areas of west China, which assessed the effects of safe motherhood program, showed that the percentage of mothers who received the first prenatal visit during the early 3 months changed from $38.9 \%$ to $76.1 \%$, the percentage of mothers who received prenatal care services changed from $82.6 \%$ to $98.3 \%$, the percentage of mothers who were referred to a hospital for delivery changed from $62.7 \%$ to $94.5 \%$ and the percentage of deliveries in hospitals changed from $31.1 \%$ to $87.3 \%$ (Liu, Yan, \& Wang, 2010).

Despite the rise in the mentioned indices in 2013 compared with 2005 , only $38.8 \%$ of mothers received preconception care and only $41.6 \%$ fully received integrated maternal health care services. The results of a study by Islam and Odland (2011) showed that $11.2 \%$ of mothers received prenatal care and $6.4 \%$ received postnatal care; the reported rates were lower than the national level (Islam \& Odland, 2011).

Although the family physician program must provide preconception, prenatal and postnatal care via home visits and follow-ups, it seems that the opportunity to provide care according to defined standards is overlooked.

It is expected to monitor the performance of staff so as to motivate them to use a set of integrated maternal health care services, which includes routine and exclusive measures for preconception, prenatal and postnatal care. The active service delivery for pregnant women can help to increase the utilization of standard prenatal care. 
Results of the difference-in-differences model showed that the odds ratio of continuity of postnatal care among women who were satisfied with postpartum care increased by more than twofold.

Research by Lubbock and Stephenson (2008) has shown that the utilization of prenatal care by mothers depends on their perception of the services (Lubbock \& Stephenson, 2008); in addition, the continuity of care depends on the quality of care, trust in service providers and mutual respect (Downe, Finlayson, Walsh, \& Lavender, 2009). Patients' satisfaction is an important factor in the quality of health care and has an important role in the utilization of prenatal care (Teijlingen, Hundley, Rennie, Graham, \& Fitzmaurice, 2003; Aldana, Piechulek, \& Al-Sabir, 2001).

There was a positive relationship between continuity of care and the quality of services; on the other hand, the continuity of services is linked with patients' satisfaction (Cabana \& Jee, 2004; Sans-Corrales et al., 2001). Satisfaction with services is the main factor determining the utilization of health services (Aldana, Piechulek, \& Al-Sabir, 2001). Many programs tried to maximize the quality and access to services, resulting in increased patient satisfaction and thus, greater use of services (Shelton \& Davis, 1996). People's access can determine whether the patients prefer to get health care or not; the quality of care can affect patients' decision whether to continue using the service or not (Bertrand, Hardee, Magnani, \& Angle, 1995).

There is much evidence showing that increased access to skilled manpower directly leads to improved maternal and neonatal health indicators (Anand \& Bärnighausen, 2007; Anand \& Bärnighausen, 2004; Speybroeck, Kinfu, Dalpoz, \& Evans, 2006; Gupta et al., 2011). However, the results of this study showed that the use of midwives staffs in family physician program did not have an impact on the change in the indices of prenatal and postnatal care; it indicated that the increase in the density of staff alone was insufficient. In other words, the quality of primary health care is strongly dependent on the use of trained health workers. In addition, manpower planning and management can have an important role in the improvement of prenatal care.

Overall, several studies have examined the associations between human resources and health indicators and have found different results; some have reported positive associations between these constructs, while others have reported negative association (Frankenberg \& Thomas, 2001; Piérard, 2009; Busato \& Künzi, 2008; Needleman, Buerhaus, Mattke, Stewart, \& Zelevinsky, 2002; Gulliford, 2002; Frankenberg, 1995, Aiken, Clarke, Sloane, Sochaski, \& Silber, 2002; Farzadfar et al., 2012).

The results of these previous studies are influenced by various factors. For instance, many of these studies did not assess the effects of health worker density on health indicators at the individual level, but rather, they have calculated health indicators at the level of district or province or country. The relationship between the variables in a district may not reflect the relationship between variables at the individual level. These studies also did not control for socioeconomic status at the individual or family level; instead, they usually used variables such as the average level of education within a district, although the socioeconomic statuses of individuals are a preferred measure that can increase the precision of the study. Nevertheless, previous studies have shown that the measurement of cumulative socioeconomic variables is valid at the district level (Ferrante, Gonzalez, Pal, \& Roetzheim, 2003).

In many of these studies, there is no data about the actual use of family physician services by each individual (Campbell, Ramirez, Perez, \& Roetzheim, 2003). One of the strengths of the present study is that the data was collected at an individual level; another is the use of Matchit statistical model. A third strength of this study was that it compared the services received by mothers with pre-defined standards proposed by the Ministry of Health and Medical Education, made an assessment of the services, and evaluated the consistency between the services provided and the standard services. It showed how closely service providers are following the standards when providing primary health care services. The study was limited by the fact that we only had two time points for data collection, in 2005 and 2013, and therefore we were not able to show changes occurring during the years between 2005 and 2013.

\section{Conclusion}

Following the initiation of the family physician program, it is expected to observe an increase in both quantity and quality of services. The results of this study showed that despite the increase in indices of maternal health program in 2013 compared with 2005, some indicators of quality of preconception, prenatal and postnatal care are still below $50 \%$. On the other hand, the results of this study showed that the use of midwives in family physician program did not result in a significant change in the indices of prenatal and postnatal care.

Strong governmental policies and financial support are very important factors needed for a community-based intervention program. On the other hand, intervention strategies should include comprehensive programs for 
technical support, manpower training, health education and community mobilization and participation, all of which are equally important.

Certainly, without skilled manpower in the right time and place, it is not possible to achieve the goals of health for all, primary health care objectives and objectives set by the SDGs. This means that increasing the density of manpower alone will not be effective. The quality of primary health care services highly depends on the use of trained health care staff. Human resources planning and management can have an important role in the improvement of prenatal care. Therefore, monitoring and evaluation of inputs, including human resources, processes and outputs of health systems are necessary to identify barriers or facilitators to achieve the SDGs for maternal health.

\section{Acknowledgments}

The authors would like to thank the Ministry of Health and Medical Education, Research deputy of Shahid Beheshti University of Medical Sciences, Health deputy of Kurdistan University of Medical sciences for their supports. It is worth mentioning that this study was part of a $\mathrm{PhD}$ thesis on Reproductive Health which was conducted by Shayesteh Hajizadeh (PhD student of Reproductive Health, School of Nursing and Midwifery, Shahid Beheshti University of Medical Sciences).

\section{Conflict of Interest}

The authors declare that there is no conflict of interests regarding the publication of this paper.

\section{References}

Aiken, L. H., Clarke, S. P., Sloane, D. M., Sochalski, J., \& Silber, J. H. (2002). Hospital nurse staffing and patient mortality, nurse burnout, and job dissatisfaction. JAMA, 288, 1987-1993. http://dx.doi.org/10.1001/jama.288.16.1987

Aldana, J. M., Piechulek, H., \& Al-Sabir, A. (2001). Client satisfaction and quality of health care in rural Bangladesh. Bulletin of the World Health Organization, 79, 512-517. http://dx.doi.org/10.1590/S0042-96862001000600006

Anand, S., \& Barnighausen, T. (2004). Human resources and health outcomes: cross-country econometric study. The Lancet, 364, 1603-1609. http://dx.doi.org/10.1016/S0140-6736(04)17313-3

Anand, S., \& Barnighausen, T. (2007). Health workers and vaccination coverage in developing countries: an econometric analysis. The Lancet, 369, 1277-1285. http://dx.doi.org/10.1016/S0140-6736(07)60599-6

Bakhshian, F., \& Jabbari, H. (2009). Effectiveness of health services for mothers in Iran health system. Iran Journal of Nursing, 22, 43-54. [In Persian].

Bertrand, J. T., Hardee, K., Magnani, R. J., \& Angle, M. A. (1995). Access, quality of care and medical barriers in family planning programs. International Family Planning Perspectives, 64-74. http://dx.doi.org/10.1016/j.ijgo.2015.05.007

Busato, A., \& Kunzi, B. (2008). Primary care physician supply and other key determinants of health care utilisation: the case of Switzerland. BMC health services research, 8,8 . http://dx.doi.org/10.1186/1472-6963-8-8

Cabana, M. D., \& Jee, S. H. (2004). Does continuity of care improve patient outcomes. J Fam Pract, 53, 974-980. http://dx.doi.org/10.1016/j.pec.2015.07.004

Campbell, R. J., Ramirez, A. M., Perez, K. \& Roetzheim, R. G. (2003). Cervical cancer rates and the supply of primary care physicians in Florida. FAMILY MEDICINE-KANSAS CITY-, 35, 60-67. [PubMed]

Downe, S., Finlayson, K., Walsh, D., \& Lavender, T. (2009). 'Weighing up and balancing out': A meta synthesis of barriers to antenatal care for marginalised women in high - income countries. BJOG: An International Journal of Obstetrics \& Gynaecology, 116, 518-529. http://dx.doi.org/10.1111/j.1471-0528.2008.02067.x.

Faezadfar, F., Murray, C. J., Gakidou, E., Bossert, T., Namdaritabar, H., Alikhani, S., ... Ezzati, M. (2012). Effectiveness of diabetes and hypertension management by rural primary health-care workers (Behvarz workers) in Iran: A nationally representative observational study. The Lancet, 379, 47-54. http://dx.doi.org/10.1016/S0140-6736(11)61349-4

Ferrante, J. M., Gonzalez, E. C., Pal, N. \& Roetzheim, R. G. (2000). Effects of physician supply on early detection of breast cancer. The Journal of the American Board of Family Practice, 13, 408-414. 
http://dx.doi.org/10.3122/15572625-13-6-408

Frankenberg, E. \& Thomas, D. (2001). Women's health and pregnancy outcomes: Do services make a difference? Demography, 38, 253-265. http://dx.doi.org/10.1353/dem.2001.0014

Frankenberg, E. (1995). The effects of access to health care on infant mortality in Indonesia. Health Transition Review, 143-163.http://dx.doi.org/10.3122/15572625-13-6-408

Gulliford, M. C. (2002). Availability of primary care doctors and population health in England: is there an association? Journal of Public Health, 24, 252-254. http://dx.doi.org/ 10.1093/pubmed/24.4.252. [PubMed] [Cross Ref]

Guo, Y., Zakus, D., \& Liang, H. (2008). China: policy and practice of MCH since the early 1990s. Maternal and Child Health Journal, 12, 139-148. http://dx.doi.org/10.1007/s10995-007-0305-1

Gupta, N., Maliqi, B., Franca, A., Nyonator, F., Pate, M. A., Sanders, D., ... Daelmans, B. (2011). Human resources for maternal, newborn and child health: from measurement and planning to performance for improved health outcomes. Hum Resour Health, 9, 16. http://dx.doi.org/ 10.1186/1478-4491-9-16

Islam, M., \& Odland, J. (2011). Determinants of antenatal and postnatal care visits among Indigenous people in Bangladesh: a study of the Mru community. Rural \& Remote Health, 11. [PubMed]

Jiang, M., Foster, E. M., \& Gibson-Davis, C. M. (2011). Breastfeeding and the child cognitive outcomes: A propensity score matching approach. Maternal and child health journal, 15, 1296-1307. http://dx.doi.org/10.1007/s10995-010-0677-5

Keshtkar, A., Changizi, N., \& Majdzadeh, R. (2008). Analysis of trends in maternal mortality between 2001-2006 assess risk factors and classify provinces. Ministry of Health and Medical Education, Office of Maternal Health. [Persian]

Khayyati, F., Motlagh, M. E., Kabir, M., Kazemeini, H., \& Jafari, N. (2011). The Role of Family Physician in Case Finding, Referral, and Insurance Coverage in the Rural Areas. Iranian journal of public health, 40. [PMC free article] [PubMed]

Langer, A., Nigenda, G., Romero, M., Rojas, G., Kuchaisit, C., Al-Osimi, M., \& Orozoo, E. (998). Conceptual bases and methodology for the evaluation of women's and providers' perception of the quality of antenatal care in the WHO Antenatal Care Randomised Controlled Trial. Paediatric and perinatal epidemiology, 12, 98-115. http://dx.doi.org/10.1046/j.1365-3016.1998.00009.x

Liu, X., Yan, H., \& Wang, D. (2010). The evaluation of "Safe Motherhood" program on maternal care utilization in rural western China: A difference in difference approach. BMC Public Health, 10, 566. http://dx.doi.org/10.1186/1471-2458-10-566.

Lubbock, L. A., \& Stephenson, R. B. (2008). Utilization of maternal health care services in the department of Matagalpa, Nicaragua. Revista Panamericana de Salud Pública, 24, 75-84. http://dx.doi.org/10.1590/S1020-49892008000800001_

Lyell, D., \& McDonnel, G. (2008). A dynamic balanced scorecard for managing health systems performance. Retrieved from http://www.systemdynamics.org/conferences/2007/proceed/papers/LYELL277. pdf.Accessed_11/19/2015

Ministry of Health and Medical Education. (2008). Report of the survey, monitoring and evaluation of reproductive health programs in Iran. Tehran: Ministry of Health and Medical Education. [persian].

Ministry of Health and Medical Education. (2009). Guideline of Integrated maternal health care for midwives and general physicians In: Department of Maternal Health. (ed.). Ministry of Health and Medical Education: Tehran. [Persian].

Ministry of Health and Medical Education. (2012). Operational guide for family physician project implementation. In Ministry of Health and Medical Education. (ed.). Tehran. [In persian].

Mohammad-Alizadeh C, S., Wahlstrom, R., Vahidi, R., Nikniaz, A., Marions, L., \& Johnsson, A. (2009). Barriers to high-quality primary reproductive health services in an urban area of Iran: Views of public health providers. Midwifery, 25, 721-730. http://dx.doi.org/ 10.1016/j.midw.2008.01.002.

Needleman, J., Buerhaus, P., Mattke, S., Stewart, M., \& Zelevinsky, K. (2002). Nurse-staffing levels and the quality of care in hospitals. New England Journal of Medicine, 346, 1715-1722. http://dx.doi.org/10.1056/NEJMsa012247 
Pierard, E. (2009). The effect of physician supply on health status as measured in the NPHS. University of Waterloo, Department of Economics. Retrieved from http://economics.uwaterloo.ca/documents/TheEffectPaperPierard_000.pdf. Accessed 11/18/2015

Raeissi, P., Ebadi Fard Azar, F., Roudbari, M., \& Shabanikia, H. (2011). The Impact of Family Physician Program on Mother and Child Health Indices in Rural Population Auspices of Mashhad University of Medical Sciences and Health Care Services, Iran; 2009. Journal of Health Administration, 14, 27-36. [In Persian]

Sans-Corrales, M., Pujol-Ribera, E., Gene-Badia, J., Pasarin-Rua, M. I., Iglesias-Perez, B., \& Casajuana-Brunet, J. (2006). Family medicine attributes related to satisfaction, health and costs. Family practice, 23, 308-316. http://dx.doi.org/10.1093/fampra/cmi112

Shelton, J., \& Davis, S. (1996). Some priorties in maximizing access to and quality of contraceptive services. Advances in Contraception, 12, 233-237. http://dx.doi.org/10.1111/j.1467-9272.2006.00568.x ·

Spybroeck, N., Kinfu, Y., Dal Poz, M. R., \& Evans, D. B. (2006). Reassessing the relationship between human resources for health, intervention coverage and health outcomes. Geneva, World Health Organization. Retrieved from http://www.who.int/hrh/documents/reassessing_relationship.pdf. Accessed 11/18/2015

Teijlingen, E. R., Hundley, V., Rennie, A. M., Graham, W., \& Fitzmaurice, A. (2003). Maternity satisfaction studies and their limitations: "what is, must still be best". Birth, 30, 75-82. http://dx.doi.org/10.1046/j.1523-536X.2003.00224.x

World Health Organization. (2008). The world health report 2008: primary health care now more than ever. Retrieved November 18th, 2015, from, http://www.who.int/whr/2008/en/

\section{Copyrights}

Copyright for this article is retained by the author(s), with first publication rights granted to the journal.

This is an open-access article distributed under the terms and conditions of the Creative Commons Attribution license (http://creativecommons.org/licenses/by/3.0/). 